\title{
PERMEABILITY OF BACTERIAL SPORES
}

\author{
IV. Water Content, Uptake, and Distribution \\ S. H. BLACK AND PHILIPP GERHARDT \\ Department of Bacteriology, The University of Michigan, Ann Arbor, Michigan
}

Received for publication November 13, 1961

\section{ABSTRACT}

Black, S. H. (The University of Michigan, Ann Arbor) and Philipp Gerhardt. Permeability of bacterial spores. IV. Water content, uptake, and distribution. J. Bacteriol. 83:960967. 1962.-Dormant and germinated spores of Bacillus cereus strain terminalis were examined for water properties. Respectively, they exhibited a mean density of 1.28 and $1.11 \mathrm{~g} / \mathrm{ml}$, a water content of 64.8 and $73.0 \%$, and a total water uptake of 66.6 and $75.6 \%$, based on spore weight, or 86.0 and $83.9 \%$, based on spore volume. The results confirmed a previous report that internal and external water are in virtually complete equilibrium, but refuted a prevailing hypothesis that heat resistance is attributable to a dry core. A model of spore ultrastructure that evolved from the cumulative results pictures a moist, dense, heteroporous core. A new hypothesis is formulated as an explanation for thermostability in spores and possibly in other instances; it postulates the occurrence of an insolubly gelled core with cross-linking between macromolecules through stable but reversible bonds so as to form a high-polymer matrix with entrapped free water.

Preceding studies (Black and Gerhardt, 1961; Gerhardt and Black, 1961) have established that dormant spores of Bacillus cereus strain terminalis are permeable indiscriminately to small solutes, which enter into the spore passively and to a degree governed by molecular weight, charge, and lipid insolubility. Germinated spores, viable but arrested, display some increases in permeability, notably to water (Black and Gerhardt, 1962). Consequently, the line of experiment led to determinations of the mean density and moisture contents for both spore types, using masses of clean and reproducibly wetted spores with a known amount of interstitial water. Permeability measurements with tritiated water then resulted in space values for total uptake and made it possible to ascertain whether internal and external water are in equilibrium. Analysis of the disposition of water and other permeating solutes within the spore led to a new concept of why spores are thermostable.

\section{MATERIALS AND METHODS}

Dormant spores of the test organism were produced and cleaned as described previously (Black and Gerhardt, 1961). Heavy suspensions of spores were germinated by shaking them for $30 \mathrm{~min}$ at $30 \mathrm{C}$ in Trypticase-soy broth supplemented with L-alanine and adenosine, further development being prevented by washing (Black and Gerhardt, 1962). Vegetative cells were grown in modified G-medium, harvested in the logarithmic phase of growth before fragmentation and granulation (Hashimoto, Black, and Gerhardt, 1960), and washed three times in deionized water.

The space technique was employed both to measure total water uptake and to interpret the distribution of penetrating substances within the spore. The basic equation that expresses uptake by the spore pack $(S)$ and a derivation that allows determination of mean density are given below. Uptake by the spores themselves is expressed as an $R$ value (Black and Gerhardt, 1961).

The tritium-labeled water used in the wateruptake studies was assayed in the following manner. A 50- $\mu$ liter sample was pipetted into a standard, low-potassium, 20-ml counting vial, and a 50 - $\mu$ liter water rinse from the pipette was added. The water was then diluted with $3 \mathrm{ml}$ of absolute methanol and $8 \mathrm{ml}$ of a toluene solution containing $0.01 \%$ (w/v) 1,4-di-2-(5-phenyloxazolyl)-benzene and $0.4 \%(\mathrm{w} / \mathrm{v})$ 2,5-diphenyloxazole. Sample vials were prepared in triplicate. After equilibration at $0 \mathrm{C}$ for $24 \mathrm{hr}$, the samples were counted three times at the same temperature in a liquid scintillation spectrometer operated at 
1,100 v. Activities were between 100,000 and 200,000 count $/ \mathrm{min}$.

\section{RESULTS}

Determination of spore density. When packed cells of known volume $\left(V_{p}\right)$ are mixed with a test solute of known volume $\left(V_{s}\right)$ and concentration $\left(C_{o}\right)$ and are then repacked, a measure of the total solute uptake by the pack $\left(S^{v}\right)$ can be made from the dilution of solute in the supernatant fluid $\left(C_{f}\right)$ :

$$
S^{v}=\frac{V_{s}}{V_{p}}\left(\frac{C_{o}}{C_{f}}-1\right)
$$

The space value $\left(S^{v}\right)$ is defined as the fractional volume of the cell pack available to the test solute. In previous studies (Black and Gerhardt, 1961, 1962; Gerhardt and Black, 1961), the pack weight $\left(W_{p}\right)$, which can be determined accurately, has been substituted for the pack volume $\left(V_{p}\right)$, resulting in a pack space value based on weight $\left(S^{w}\right)$. Such substitution of cellular weight for volume in determining other than relative values is justified only when the density of cells approximates unity; the density of spores, however, has been reputed to be a high as $1.46 \mathrm{~g} / \mathrm{ml}$ (McIntosh and Selbie, 1937) and as low as $1.2 \mathrm{~g} / \mathrm{ml}$ (Lamanna, 1952). For volume-distribution measurements, therefore, it became necessary to determine accurately the density of the test organism. The basic equation (1) of the space technique suggested a means by which this could be done.

The pack volume $\left(V_{p}\right)$ consists of two components, the cell volume $\left(V_{c}\right)$ and the interstitial volume $\left(V_{\text {in }}\right)$, but may also be expressed as

$$
V_{p}=\frac{W_{c}}{\rho_{c}}+\frac{W_{\text {in }}}{\rho_{\mathrm{H}_{2} \mathrm{O}}}
$$

where $W_{c}$ and $W_{\text {in }}$ are the weights of cells and interstitial water and $\rho_{c}$ and $\rho_{\mathrm{H}_{2} \mathrm{O}}$ are their respective densities. When this expression is substituted for $V_{p}$ in equation 1 , the following equation results:

$$
S^{v}=\frac{V_{s}}{W_{c} / \rho_{c}+W_{\mathrm{in}} / \rho_{\mathrm{H}_{2} \mathrm{O}}}\left(\frac{C_{o}}{C_{f}}-1\right)
$$

This equation can be simplified for routine determination of $S^{v}$. Only a small error is introduced if the predominating $\rho_{c}$ is substituted for $\rho_{\mathrm{H}_{2} \mathrm{O}}$. Since $W_{c}+W_{\text {in }}=W_{p}$, therefore

$$
S^{v}=\frac{V_{s} \rho_{c}}{W_{p}}\left(\frac{C_{o}}{C_{f}}-1\right)
$$

Or, for conversion of existing $S^{w}$ values,

$$
S^{v} \cong \rho_{c} S^{w}
$$

The fractional volume of the cells themselves available to the test solute $\left(R^{v}\right)$ can then be calculated from the equation

$$
R^{v}=\frac{S_{\mathrm{sol}}^{v}-S_{\mathrm{in}}{ }^{v}}{1-S_{\mathrm{in}}}
$$

Spore density can be approximated, of course, by directly weighing a large pack of spores $\left(W_{p}\right)$, indirectly determining the pack volume $\left(V_{p}\right)$ from the amount of water needed to bring to a fixed volume, and then dividing $W_{p}$ by $V_{p}$. A sizable error is introduced into both the weight and volume determinations by the presence of interstitial water. An accurate value for spore density, however, can be calculated by repeated and diminishing approximation, using equation 3 .

A known pack weight ( $W_{c}$ about $10 \mathrm{~g}$ ) of clean spores was exposed to a known volume $\left(V_{s}\right)$ of a $1 \%(\mathrm{w} / \mathrm{v})$ solution of nonpenetrating dextran, and $C_{o}$ and $C_{f}$ determined as in a typical experiment for measuring interstitial space (Black and Gerhardt, 1961). With an initial assumption that $\rho_{c}=1.0$ and $W_{\text {in }}=0$, a trial value for the interstitium $\left(S_{\text {in }}^{v}\right)$ was calculated using equation 3 . $W_{\text {in }}$ was then estimated $\left(W_{\text {in }}=S_{\text {in }}^{v} \times W_{p}\right)$ and subtracted from $W_{p}$ to give a trial value for $W_{c}$. The spores were then washed free of dextran, repacked, weighed to the nearest $0.01 \mathrm{~g}$, and transferred quantitatively to a 25 -ml volumetric flask. The volume of water used to bring the suspension to volume was totalled to the nearest $0.1 \mathrm{ml}$. A trial value for $V_{c}$ was then obtained by subtracting the total added water and the estimated interstitial water; that is, $V_{c}=25-$ $V_{\text {water added }}-V_{\text {in }}$. The spore density $\left(\rho_{c}\right)$ was calculated as the ratio $W_{c} / V_{c}$, although the value so obtained was only a first trial estimate. By repeated estimation and substitution into equation 3 , however, a final value for spore density was calculated, the error becoming vanishingly small by the third recalculation.

Four separate experiments, each with five tubes of spores, were conducted using dormant and also germinated spores. Sample calculations, based on the average values for the 20 tubes in each case, are given in Table 1 . The resulting density for dormant spores was $1.28 \mathrm{~g} / \mathrm{ml}$ and for germinated spores, 1.11 . 
TABLE 1. Density calculations for dormant and germinated spores

\begin{tabular}{|c|c|c|c|c|c|}
\hline \multirow{2}{*}{ Calculation } & \multirow{2}{*}{ Value determined ${ }^{*}$} & \multicolumn{2}{|c|}{$\begin{array}{l}\text { Dormant spores, } \\
\text { approximation no. }\end{array}$} & \multicolumn{2}{|c|}{$\begin{array}{l}\text { Germinated spores, } \\
\text { approximation no. }\end{array}$} \\
\hline & & 1 & 2 & 1 & 2 \\
\hline A & $V_{8}$ & 10.00 & 10.00 & 10.00 & 10.00 \\
\hline B & $W_{p}$ & 10.09 & 10.09 & 8.55 & 8.55 \\
\hline C & $C_{o} / C_{f}$ & 1.068 & 1.068 & 1.073 & 1.073 \\
\hline D & Water added & 16.95 & 16.95 & 17.23 & 17.23 \\
\hline $\mathrm{E}$ & $S_{\text {in }}$ & 0.067 & 0.086 & 0.085 & 0.094 \\
\hline$F(B \times E)$ & $W_{\text {in }}$ & 0.68 & 0.87 & 0.73 & 0.80 \\
\hline$G(B-F)$ & $W_{c}$ & 9.41 & 9.22 & 7.82 & 7.75 \\
\hline $\mathrm{H}(\mathrm{D}+\mathrm{F})$ & Total water & 17.63 & 17.82 & 17.96 & 18.03 \\
\hline $\mathrm{I}(25-\mathrm{H})$ & $V_{c}$ & 7.37 & 7.18 & 7.04 & 6.97 \\
\hline $\mathbf{J}(\mathrm{G} / \mathrm{I})$ & $\rho_{c}$ & 1.277 & 1.283 & 1.109 & 1.110 \\
\hline
\end{tabular}

* Symbols are defined in the text.

Determination of water content. The method described above for calculating the weight of interstitial water in spore packs provided, in addition, a means for accurately determining the water content of spores that are in a reproducible state of hydration (i.e., an aqueous suspension packed by centrifugation for $30 \mathrm{~min}$ at $17,000 \times$ $g$ ). After determination of interstitial water $\left(W_{\text {in }}\right)$, packs of spores were transferred quantitatively to tared drying receptacles and dried to constant weight by three methods: in a vacuum over phosphorus pentoxide, in an oven at $102 \mathrm{C}$, and by lyophilization.

Comparative results on the water content of dormant or germinated spores and of vegetative cells are summarized in Table 2 . Two conclusions are at once apparent: the measurements are essentially independent of the method used for desiccation, and there is an increase from $64.8 \%$ wet wt for dormant spores to $73.0 \%$ for germinated spores and to $76.6 \%$ for vegetative cells.

That bacterial spores contain relatively little water was early proposed by Davenport and Castle (1895), on the basis of the light refractivity which had in fact led to Ehrenberg's (1838) discovery of spores. Yet surprisingly few experiments have been recorded which directly contrast the water content of spores with that of homologous vegetative cells. The earliest experiments to come to our notice are those of Virtanen and Pulkki (1933) and Henry and Friedman (1937). In both studies, a bulk-weighing technique did not reveal differences in either of two species investigated. The former workers, however, inadequately defined the state of hydration of their cell preparations. The latter,
TABLE 2. Water content of spores and vegetative cells desiccated in various ways

\begin{tabular}{cccc}
\hline \multirow{2}{*}{ Method of desiccation } & \multicolumn{3}{c}{ Water content } \\
\cline { 2 - 4 } & $\begin{array}{c}\text { Dormant } \\
\text { spores }\end{array}$ & $\begin{array}{c}\text { Germinated } \\
\text { spores }\end{array}$ & $\begin{array}{c}\text { Vegetative } \\
\text { cells }\end{array}$ \\
\hline & $\%$ & $\%$ & $\%$ \\
Oven $(102 \mathrm{C}) \ldots \ldots \ldots$ & 65.1 & 72.7 & $\mathbf{7 6 . 8}$ \\
$\mathrm{P}_{2} \mathrm{O}_{5}($ in vacuum) $\ldots \ldots$ & 64.1 & 73.3 & 76.4 \\
Freeze-dry $\ldots \ldots \ldots \ldots$ & 65.0 & 73.0 & \\
Average ............... & 64.8 & 73.0 & 76.6 \\
\hline
\end{tabular}

seeking to meet this criticism, used a known weight of cells, which had previously been blotted dry with filter paper; the blotted cells were then air-dried, desiccated over $\mathrm{CaCl}_{2}$, and finally oven-dried. B. megaterium spores, through this process, lost $58 \%$ of their weight while the vegetative cells lost $80 \%$; similarly, spores of $B$. cereus var. mycoides lost $71 \%$ while the vegetative forms lost $88 \%$. More recently, Fitz-James (1953) has employed alcohol-rinsed spores for water determinations, the results supporting the belief that dormant spores are low in water content but lose solids and gain water during germination. Ross and Billing (1957), in microinterferometry studies, have shown that a difference occurs in the water content of spores and vegetative cells, but their calculations of refractive indexes are attended by limiting assumptions.

We believe that our method and the results on water content and density are reliable to a degree not heretofore attained. The following features are thought to be especially significant: starting material of a high degree of purity and homoge- 
neity and in sufficient amount to permit macrodeterminations; full and reproducible cellular hydration, defined by standardized conditions of centrifugation; minimization and accurate determination of interstitial water; adequate replication; and use of several methods of desiccation. The presence of small amounts of poly- $\beta$-hydroxybutyrate granules in the spore suspensions is estimated to cause an error of less than $1 \%$ in the final values.

Determination of water uptake. Murrell and Scott (1957) and Murrell (1961) have concluded, from experiments measuring deuterium-water exchange, that almost all ( $96 \%$ or more) of the water in a dormant spore pack mixes freely with external water. We sought to confirm their findings and to obtain quantitative values for water distribution in the cells themselves, correcting for interstitial water.

Tritium-labeled water was employed in typical space determinations, comparing dormant and germinated spores. A suspension of cells was packed, weighed, resuspended in a known volume of tritium-labeled water of known activity, allowed to equilibrate for $15 \mathrm{~min}$ at $4 \mathrm{C}$, and repacked. The supernatant water was decanted, clarified, counted, and the interstitium-corrected $R^{w}$ value calculated.

The results are summarized in Table 3 , which also includes figures to allow judgment of the variability and reliability of the antecedent $S^{w}$ values. For dormant spores, the $R^{w}$ value was $66.6 \%$; this weight-based permeability measurement is not significantly different from the comparable water content value of $64.8 \%$. The $R^{w}$ of $75.6 \%$ for germinated spores also compares favorably with the water content of this cell type, $73.0 \%$. These near equalities confirm that a free interchange of water exists across the spore surface; that is, the spore water is in equilibrium with the surrounding water.

It is conceivable that the results may reflect

TABLE 3. Uptake of tritium-labeled water by spores

\begin{tabular}{c|c|c|c|c|c}
\hline \multirow{2}{*}{ Spore type } & \multicolumn{2}{|c|}{$S^{w}$} & $R^{w}$ & $R^{v}$ \\
\cline { 2 - 5 } & Tubes & Range & Mean & & \\
\hline & $n o$. & $\%$ & $\%$ & $\%$ & $\%$ \\
Dormant..... & 20 & $57.3-76.8$ & 70.3 & 66.6 & 86.0 \\
Germinated... & 10 & $76.1-86.3$ & 78.0 & 75.6 & 83.9 \\
\hline
\end{tabular}

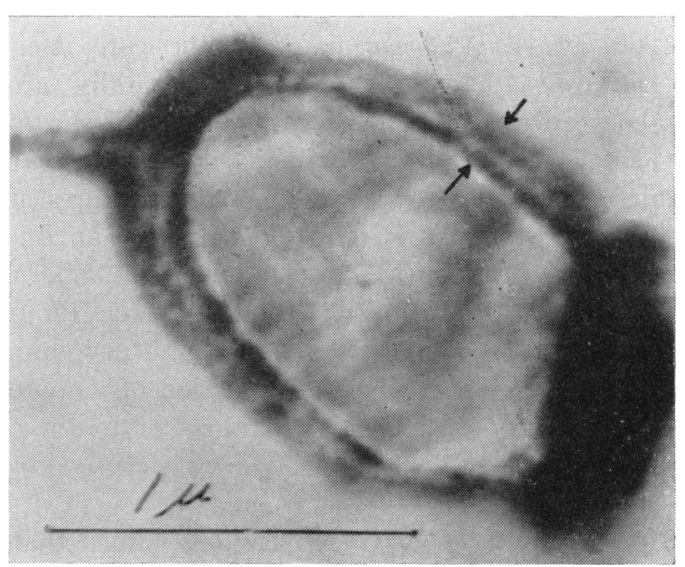

FIG. 1. Representative electron micrograph of a medially sectioned spore in a pack. The arrows indicate a measurement to obtain the average thickness of wall external to cortex, from which the apparent fractional volume was calculated (see Table 4).

not only molecular water exchange but also nonspecific exchange between the tritium and the hydrogen of the spore. An experiment in which the incubation period was changed from $15 \mathrm{~min}$ to 5,30 , or $60 \mathrm{~min}$ did not give different results from those shown in Table 3. Murrell (1961) found only negligible exchange of deuterium and spore hydrogen. It thus seems that interference from nonspecific exchange is minor.

\section{DISCUSSION}

The above results, together with those published previously on spore permeability, permit an interpretation of where water and permeating solutes are located in the spore structure. Knowledge of the distribution of water in dormant spores should resolve hypotheses that attribute spore thermostability to a restricted water content.

Hypothesis of a dry spore. The notion that the entire spore is low in water content, impervious, and therefore resistant has been discounted by observations of extensive water and solute permeation (Gerhardt and Black, 1961; Murrell, 1961).

Hypothesis of a dry core. More plausible is a prevailing hypothesis that predicts the existence of a central core kept relatively dry in the dormant spore (Lewith, 1890; Rode and Foster, $1960,1961)$, possibly by compressive contraction of an internal sheath (Lewis, Snell, and Burr, 
1960) or colloidal shrinkage of the core itself (Darányi, 1927). Dry proteins generally are relatively thermostable, and it has been shown (Pasteur, 1861; Rode and Foster, 1960) that microorganisms survive higher temperatures if dried, although dormant spores provide an important exception (Murrell and Scott, 1957). A number of observations (Rode and Foster, 1960) are consistent with the hypothesis of a dry core, notably that only the central portion of a spore is refractive to light and stains, both these properties being lost when the spore is crushed or germinated.

Murrell (1961), however, has determined that the density of spore dry matter is 1.3 to 1.5 in four species. From this and the water content of spore pellets, he has estimated that any dry space in the spore volume is likely to be small, i.e., less than $10 \%$. Using our value for water content of spores, we arrived at a similar conclusion.

To this negating evidence can be added the present results on spore permeability to water. By direct measurement on electron micrographs of medially sectioned, packed spores (Fig. 1), an approximation was made of the fractional volume occupied by spore coat external to the core. This represents at most about $54 \%$ of the spore volume, and less if the cortex is excluded (Table 4). Other approximations have resulted in about the same values (e.g., Lamanna and Mallette, 1959). This apparent space of the coat, however, must be corrected for the fact that part of it is occupied by dry matter and is not available to permeating water. The apparent coat space available to water thus becomes about $45 \%$ or less of the spore. The experimentally determined space value $\left(R^{v}\right)$ for water, however, was $86 \%$ (Table 3), a decidedly greater value than can be accounted for by the coat alone. Moreover, if water were limited to a peripheral region of the spore, the equilibrium permeability measurements with low molecular weight solutes should approximate that with water, but they do not (Gerhardt and Black, 1961).

Clearly, the results were not in agreement with the hypothetical existence of a dry core of the dimensions observed. Instead, the permeability determinations suggested that water is distributed throughout the spore, although probably unevenly, with the core having relatively little water and a correspondingly high density. The apparent space of the entire spore available to
TABLE 4. Fractional volumes available to water in spore structure

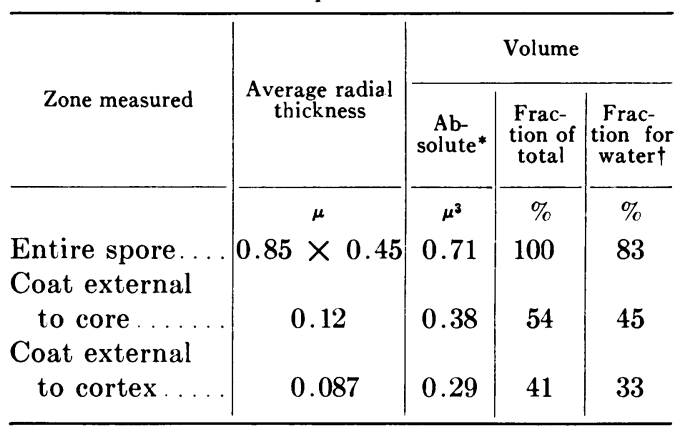

* Based on an assumption that the spore is a perfect prolate ellipsoid of revolution (Knaysi, 1946) and calculated from the equation, $V=$ $\frac{4 \pi a b^{2}}{3}$, where $a$ is the radial length and $b$ is the radial breadth.

$\dagger$ Fraction for water $=\%$ of total volume $\times$ spore density $\times \%$ water content $\times$ specific volume of water.

water was $83 \%$ (Table 4), agreeing reasonably with the determined $R^{v}$ value of $86 \%$ (Table 3 ). Some error in absolute values occurs, attributable to the probable variation in density within the spore structure, but the above values are comparable since both assume uniform density.

The permeability measurements with different solutes (Gerhardt and Black, 1961) have indicated some other characteristics of the internal region, which because of volume considerations can best be assumed to be the core. In addition to being moist, it also seems to be heteroporous, since small lipid-soluble molecules (e.g., ethylene glycols) permeate to a regularly greater extent as their molecular weight decreases. The core also seems to contain or be surrounded by lipid-like substance, since lipid-insoluble compounds such as sugar are limited in their degree of penetration. The average $R^{w}$ value for glucose is $40 \%$ on a weight basis and becomes $51 \%$ on a volume basis; this $R^{v}$ value was found to agree roughly with the apparent water space available in the region external to the core (Table 4). Furthermore, the average $R^{w}$ value for ethylene glycol is $53 \%$ and the $R^{v}$ value, $68 \%$. Apparently it and similar lipophilic molecules can penetrate not only the coat region of the dormant spore but also beyond. to an extent approaching that which water enters. Upon spore germination, however, glucose penetrates to a much greater extent $\left(R^{w}=51 \%\right.$, 
$R^{v}=56 \%$ ) than before, apparently now limited by its molecular weight but no longer by its lipid insolubility (Black and Gerhardt, 1962). The lipidlike component so predicted in dormant but not germinated spores is being sought.

A model of ultrastructure in the dormant spore thus emerges from the cumulative results. The outermost envelope, the exosporium, is isoporous, crystalline, loose-fitting, and leaky. The principal coat region is layered, coarsely heteroporous, wet, and fully permeable. The nature of the cortex is quite unknown but conceivably is lipidlike. The "protoplast" of the spore, the core, is dense, finely heteroporous, moist, permeable to small molecules, and possibly lipidlike.

Proposed hypothesis. If the core is not dry, what might account for heat resistance and yet reconcile the above and other apparent features of spore ultrastructure? We propose an alternative hypothesis: the core of the dormant spore exists as an insoluble and heat-stable gel, in which crosslinking between macromolecules occurs through stable but reversible bonds so as to form a highpolymer matrix with entrapped free water.

In envisioning this hypothesis, we sought a comparable chemical system in which the basic concepts of an insoluble gel and reversible heat stability were exhibited. An illustrative example was found in synthetic disulfide derivatives of thiolated gelatins (Benesch and Benesch, 1958), which have been marketed as Thiogels (Schwarz BioResearch, Inc., 1960). Sulfhydryl groups are linked to the protein by a stable, covalent peptide bond at primary amino groups, the resulting - $\mathrm{SH}$ groups having great reactivity for other macromolecules and also heavy metals. The thiolated gelatin molecules are readily soluble and form heat-reversible gels, involving only hydrogen bonds. Such gels when oxidized, however, quickly form an insoluble and heat-stable gel, the molecules of which are cross-linked through disulfide bridges. This high-polymer matrix entraps free water, allowing free diffusion by molecules of low molecular weight but excluding molecules of molecular weight greater than a few hundred. The cross-linked gel, moreover, can be reversed to the soluble and heat-labile form by the application of a reducing agent.

The situation in the spore, although possibly analogous in a general way, may well be different in detail and almost certainly more complex than that in thiolated gelatin gels. Spore polypeptides and proteins would likely be involved, but nucleic acids, polysaccharides, and other cytopolymers are essential to viability and would require protection; there is the example of interpolymer linking between thiolated gelatin and starch, however, which allows for this possibility. Cross-linking by disulfide bridges is well recognized as a protein-stabilizing mechanism and is consistent with the fact that spore protein is unusually high in thiol groups (Vinter, 1959); Vinter in fact has posed an analogy between the structure of spores and inert proteins like keratin. Cross-linking by other than disulfide bonds may also occur; examples are seen in calcium crosslinking of $\alpha_{s^{-}}$and $\kappa$-casein to form a micelle unusually stable to heat (Waugh, 1958), and in the proposed intermolecular linking through hydrogen bonds or between hydrophobic groups in bacterial flagella (Koffler, 1957). The oxidative formation of disulfide bridges in thiolated gelatin gels is not inconsistent with the frequent occurrence of oxidation-reduction reactions in cells, and brings to mind the observations that a burst in oxygen demand accompanies aerobic spore formation (Halvorson, 1957) and that reducing conditions from hydrogen sulfide formation may account for "cystine inhibition" of spore formation (Vinter, 1959). The reversibility of heatstabilizing linkages is a feature essential for assuming a comparable system in spores, where the characteristic thermostability of dormancy is quickly changed upon germination.

The proposed hypothesis and the example of cross-linked gelatin also fit the above model of spore ultrastructure. The coats and possibly also the cortex would have no direct bearing on heat resistance. Their disproportionate content of cystine-sulfhydryl groups (Vinter, 1960), however, is believed to account for the radiation resistance of spores (Vinter, 1961a) and could reconcile the apparently different basis for and occurrence of the two types of resistance (Black, Hashimoto, and Gerhardt, 1960; Vinter, 1961b). It appears that the core is the location of the hypothetical heat-protective mechanism. The concept of a gel in the core is consistent with the known physical state of cytoplasm, and the reversible formation of an insoluble and thermostable high-polymer matrix is not an unreasonable extension. The fibrillar network of polymers could account for the unusual density and also the light refractivity of the spore core. Such a 
matrix would account for the observed moisture in the core, the complete permeation by external water, and the equilibration of internal and external water. The proposed hypothesis also fits the observed permeability of the core to solutes: an amorphous mixed network of polymers would be expected to be heteroporous so that small molecules would diffuse into it in relation to their molecular size, as observed; larger molecules would be excluded, as exemplified both in the spores and in the cross-linked thiogelatin. The model of a spore core containing or surrounded by lipidlike substance imposes a modification on the hypothesis of an insoluble gel; it must be supposed that lipoidal substance occurs in the cortex or is embedded in the matrix of the core, either situation allowing the observed penetration of water and small lipophilic solutes but not of sugars and other lipid-insoluble materials.

The hypothesis of an insolubly gelled core is thus consistent with many of the above and previous findings about spores. It has a useful example in a known chemical system. It makes sense. It even might be extended to other instances in biology where lesser degrees of heat resistance occur apparently at a molecular level, for example in the flagellar protein of thermophilic bacteria (Koffler, 1957) and in the extractable "soluble" enzymes of mesophilic bacteria (Swartz, Kaplan, and Frech, 1956) and spores (Sadoff, 1961), where different cross-linking or a more homogeneous high polymer could bring relative solubility but still a measure of resistance. Extended or restricted, the hypothesis now requires further experimental test, which we are undertaking.

\section{ACKNOWLEDGMENTS}

This investigation was supported by research grants E-619-C5 to C7 and a Predoctoral Research Fellowship (to S. H. B.) from the National Institutes of Health, U. S. Public Health Service, by a grant from the Michigan-Memorial Phoenix Project of the University, and by a contract from the Office of Naval Research, Department of the Navy. Some of the work was accomplished while the senior author held a National Science Foundation Postdoctoral Fellowship. The electron micrographs were prepared by Tadayo Hashimoto.

\section{LITERATURE CITED}

Benesch, R., AND R. E. Benesch. 1958. Thiolation of proteins. Proc. Natl. Acad. Sci. U.S. 44: 848-853.
Black, S. H., And P. Gerhardt. 1961. Permeability of bacterial spores. I. Characterization of glucose uptake. J. Bacteriol. 82:743-749.

Black, S. H., ANd P. Gerhardt. 1962. Permeability of bacterial spores. III. Permeation relative to germination. J. Bacteriol. 83: 301-308.

Black, S. H., T. Hashimoto, and P. Gerhardt. 1960. Calcium reversal of the heat susceptibility and dipicolinate deficiency of spores formed "endotrophically" in water. Can. J. Microbiol. 6:213-224.

DaránYi, J. von. 1927. Sporenbildung und kolloide Entquellung. Zentr. Bakteriol. Parasitenk., Abt. 2 71:353-357.

Davenport, C. B., and W. E. Castle. 1895. Studies on morphogenesis. III. On the acclimatization of organisms to high temperatures. Arch. Entwicklungsmech. Organ. 2:227-249.

Ehrenberg, C. G. 1838. Die Infusionstierchen als vollkommene Organismen. Verlag Leopold Voss, Leipzig.

Fitz-James, P. C. 1953. Phosphorous fractions of bacterial spores. Thesis, University of Western Ontario, London.

Gerhardt, P., and S. H. Black. 1961. Permeability of bacterial spores. II. Molecular factors affecting solute permeation. J. Bacteriol. 82:750-760.

Halvorson, H. O. 1957. Rapid and simultaneous sporulation. J. Appl. Bacteriol. 20:305-314.

Hashimoto, T., S. H. Black, and P. Gerhardt. 1960. Development of fine structure, thermostability, and dipicolinate during sporogenesis in a bacillus. Can. J. Microbiol. 6:203212.

Henry, B. S., and C. A. Friedman. 1937. The water content of bacterial spores. J. Bacteriol. 33:323-329.

KNAYSI, G. 1946. On the process of sporulation in a strain of Bacillus cereus. J. Bacteriol. 51:187-197.

KOFFLER, H. 1957. Protoplasmic differences between mesophiles and thermophiles. Bacteriol. Rev. 21:227-240.

Lamanna, C. 1952. Biological role of spores. Bacteriol. Rev. 16:90-93.

Lamanna, C., and M. F. Mallette. 1959. Basic bacteriology. Its biological and chemical background, p. 197, 2nd ed. The Williams and Wilkins Co., Baltimore.

Lewis, J. C., N. S. Snell, And H. K. Burr. 1960. Water permeability of bacterial spores and the concept of the contractile cortex. Science $132: 544-545$.

Lewith, S. 1890. Úber die Ursache der Widerstandsfähigkeit der Sporengegen hohe Temperaturen. Ein Beitrag zur Theorie der De- 
sinfection. Arch. exptl. Pathol. Pharmakol., Naunyn-Schmiedeberg's $26: 341-354$.

McIntosh, J., And F. R. Selbie. 1937. The measurement of the size of viruses by high-speed centrifugation. Brit. J. Exptl. Pathol. 18: 162-174.

Murrell, W. G. 1961. Discussion. In H. O. Halvorson [ed.], Spores II. Burgess Publishing Co. Minneapolis.

Murrell, W. G., ANd W. J. Scott. 1957. Heat resistance of bacterial spores at various water activities. Nature 179:481-482.

Pasteur, L. 1861. De l'influence de la température sur la fécondité des spores des Mucédinées. Compt. rend. 52:16-19.

Rode, L. J., ANd J. W. Foster. 1960. Mechanical germination of bacterial spores. Proc. Natl. Acad. Sci. U.S. 46:118-128.

Rode, L. J., ANd J. W. Foster. 1961. Germination of bacterial spores with alkyl primary amines. J. Bacteriol. 81:768-779.

Ross, K. F. A., AND E. Billing. 1957. The water and solid content of living bacterial spores and vegetative cells as indicated by refractive index measurements. J. Gen. Microbiol. $16: 418-425$.

SAdofF, J. 1961. Some properties of the spore catalase and some heat resistant enzymes in bacterial glucose dehydrogenase. In $\mathrm{H}$. $\mathrm{O}$.
Halvorson [ed.], Spores II. Burgess Publishing Co., Minneapolis.

Schwarz Bioresearch, Inc. 1960. Thiogel. Tech. Bull. $146 \mathrm{C}$.

Swartz, M. N., N. O. Kaplan, and M. E. Frech. 1956. Significance of "heat-activated" enzymes. Science 123:50-53.

Vinter, V. 1959. Sporulation of bacilli. VII. The participation of cysteine and cystine in spore formation by Bacillus megatherium. Folia Microbiol. 4:216-221.

Vinter, V. 1960. Spores of microorganisms. VIII. The synthesis of specific calcium- and cystinecontaining structures in sporulating cells of bacilli. Folia Microbiol. 5:217-230.

Vinter, V. 1961a. Changes in radioresistance of sporulating cells of Bacillus cereus. Nature 189:589-590.

VinTer, V. 1961b. The formation of cystine-rich structure in sporulating cells and its possible role in the resistance of spores. In $\mathrm{H}$. $\mathrm{O}$. Halvorson [ed.], Spores II. Burgess Publishing Co., Minneapolis.

Virtanen, A. I., and L. Pulkki. 1933. Biochemische Untersuchungen über Bakteriensporen. Arch. Mikrobiol. 4:99-122.

WAUGH, D. F. 1958. The interactions of $\alpha_{s}^{-}, \beta-$ and $\kappa$-caseins in micelle formation. Discussions Faraday Soc. No. 25:186-192. 